Original article

\title{
Antioxidant and DNA damage protecting activities of Eulophia nuda Lindl.
}

\author{
Vinay Kumar ${ }^{\mathrm{a}, *}$, Melissa Lemos ${ }^{\mathrm{a}}$, Mansi Sharma ${ }^{\mathrm{a}}$, Varsha Shriram ${ }^{\mathrm{b}}$ \\ ${ }^{a}$ Department of Biotechnology, Modern College of Arts, Science and Commerce, Pune 411 053, India \\ ${ }^{\mathrm{b}}$ Department of Botany, Prof. Ramkrishna More College of Arts, Commerce and Science, Pune 411 044, India
}

\section{A R T I C L E I N F O}

\section{Article history:}

Received 7 May 2013

Accepted 11 July 2013

Available online 20 August 2013

\section{Keywords:}

Antioxidants

DNA damage protection

Fenton's reagent

Lipid-peroxidation

Reactive oxygen species

\begin{abstract}
A B S T R A C T
Introduction: In recent years, natural antioxidants have seen an unprecedented importance and demand in bio-pharmaceuticals, nutraceuticals besides their use as food additives. Antioxidants act as potential prophylactic and therapeutic agents against various diseases caused by free-radicals. Plants offer tremendous source of antioxidants and are therefore being evaluated for their potentials. Eulophia nuda is an important medicinal plant used by local healers in India; however its antioxidant properties have not yet been investigated.

Methods: Aqueous (AqE), methanol (ME), aqueous-methanol (AqME) and acetone (AE) extracts of shade dried tubers were obtained and were concentrated in vacuo. Total phenols, flavonoids, ascorbic acid and carotenoids were estimated from all extracts using standard methods. Antioxidant activities of extracts were determined by total antioxidant activity, FRAP, ABTS, DPPH, and OH radical scavenging assays besides lipid peroxidation inhibition. Extracts were evaluated for protection of Fenton's reagent induced DNA damage.

Results: The results confirmed the plant as a rich source of phenols, flavonoids, vitamin $C$ and carotenoids. Among four extracts, AqME showed highest antioxidant activities as evidenced by maximum scavenging of ABTS (98\%), DPPH (87\%), and OH radicals (99\%) at $1 \mathrm{mg} \mathrm{ml}^{-1}$ concentration and showed maximal inhibition of lipid peroxidation. All extracts protected the DNA from hydroxyl-radical-induced damage. Again, AqME was proved to be best in providing protection to DNA against damage caused by freeradicals.

Conclusion: The results provides scientific basis for its traditional usage as natural antioxidant and phytotherapeutic agent. The plant possesses high amount of phenolic compounds and showed a broadspectrum antioxidant properties including DNA protection.
\end{abstract}

Copyright (c) 2013, SciBiolMed.Org and Phcog.Net, Published by Reed Elsevier India Pvt. Ltd. All rights reserved.

\section{Introduction}

Oxidative stress, induced by the generation of reactive oxygen species (ROS) consisting of both free radical compounds such as superoxide anions $\left(\mathrm{O}_{2}^{-}\right)$, hydroxyl radicals $(\cdot \mathrm{OH})$, as well as nonfree-radical compounds hydrogen peroxide $\left(\mathrm{H}_{2} \mathrm{O}_{2}\right)$, organic peroxide $(\mathrm{ROOH})$, ozone $\left(\mathrm{O}_{3}\right)$ and singlet oxygen $\left({ }^{1} \mathrm{O}_{2}\right)$ are considered as major causative factors of many of today's diseases including diabetes and cardiovascular diseases. ${ }^{1-3}$ These ROS are known as exacerbating factors in DNA damage and mutations, cellular injury, oncogenesis (as many mutagens and carcinogens acts through the ROS) and ultimately the aging process. ${ }^{4,5}$ Further,

\footnotetext{
* Corresponding author. Tel.: +91 20 25634021; fax: +91 2025650931.

E-mail addresses: vinaymalik123@gmail.com, vinaymalik123@rediffmail.com (V. Kumar).
}

ROS are considered to cause cancer and several neurodegenerative diseases such as Alzheimer's disease, Parkinson's disease, Down's syndrome, inflammation, viral infection and various other digestive disorders including ulcer and gastrointestinal disorders. 6,7

Antioxidants are considered to play an imperative role in providing protection against ROS-driven oxidative damage and associated lipid peroxidation, and DNA strand breaking. ${ }^{3}$ Even though many antioxidants of synthetic origin are available and used quite frequently, especially in food industry for preservation and prolonging the shelf-lives of food products, however, they are often being associated with quality deterioration, nutritional losses and off-flavor development. ${ }^{8}$ Furthermore, available synthetic antioxidants have been reported to exhibit toxic and mutagenic effects. ${ }^{9}$ On the other hand, their natural counterparts have an edge over them for being less- or non- toxic and hence can serve as potential drug and dietary molecules. Therefore, in recent years the 
antioxidants of phyto-origin have seen an unprecedented demand in bio-pharmaceuticals, nutraceuticals besides their use as food additives.

Medicinal plants offer an excellent source of various phytochemicals such as phenols, flavonoids, vitamins, tannins, many of which have potent antioxidant activities and therefore can be exploited in drug discovery programs as well as in the preparation of foods and pharmaceutical products. ${ }^{10}$

Eulophia nuda Lindl. (Orchidaceae), a medicinally important perennial orchid with underground tubers, is found in central and Southeast Asian regions. In India, this plant is found in tropical Himalayas, from Nepal to Assam, and in Deccan from Konkan southwards. The tubers are reported to be used against tumors, scrofulous glands of the neck, bronchitis, blood diseases and as vermifuge. ${ }^{11-15}$ Raw tubers are eaten for curing rheumatoid arthritis. ${ }^{16}$ Earlier our group has reported anti-proliferative activities of a phenanthrene derivative compound 9,10-dihydro-2,5dimethoxyphenanthrene-1,7-diol isolated from this plant against human cancer cells. ${ }^{17}$ The tubers are eaten raw and therefore make it a perfect candidate for its exploration as potential antioxidative source.

However, in spite of the fact that various medicinal values have been described by folklore and is extensively used by local healers in different parts of India, till date no scientific validation has been evidenced for antioxidant potential of this plant. This is the first report dealing with the phytochemical analyses, antioxidant potentials and oxidative DNA damage preventive activities of various organic and aqueous extracts of $E$. nuda tubers.

\section{Materials and methods}

\subsection{Plant material}

Fresh tubers of E. nuda Lindl. (synonym: Eulophia spectabilis) were collected from Belgaum region ( $\mathrm{N} 15^{\circ}$ 41.099', E 74 25.026', elevation $723 \mathrm{~m}$ ) of Western Ghats, India. The botanical identification of the plant was carried out at the Botanical Survey of India, Pune 411001, India (Ref. No. BSI/WC/Tech/2012/244).

\subsection{Preparation of plant extracts}

Shade dried tubers of $E$. nuda were finely powdered with automix blender. One Kilogram dry powder of bulbs were soaked in $3 \mathrm{~L}$ acetone, methanol, aqueous methanol (1:1) solvents (Merck, India) or distilled water separately. The crude extract was prepared by cold percolation for $24 \mathrm{~h}$ at room temperature $\left(26 \pm 2{ }^{\circ} \mathrm{C}\right)$. The filtrate was concentrated in vacuo at $40,40,56$ and $60{ }^{\circ} \mathrm{C}$ to get acetone, methanol, aqueous methanol and aqueous extracts respectively. This process was repeated thrice to get total extracts. The extracts were labeled as AE (Acetone extract), ME (Methanol extract), AqME (Aqueous Methanol extract) and AqE (Aqueous extract), and were obtained as reddish/brown solid residues with $2.44 \%, 1.84 \%, 4.20 \%$ and $3.14 \%$ yield, respectively.

\subsection{Chemicals}

All the chemicals were of analytical grade and obtained from HiMedia, Merck or Fisher while standard antioxidants were procured from Sigma-Aldrich.

\subsection{Determination of total phenols}

The total soluble phenolic content was determined by FolinCiocalteu (FC) method. ${ }^{18}$ In brief, $10 \mu \mathrm{l}$ of extract was taken and the final volume was made $2 \mathrm{ml}$ with distilled water. To this $0.5 \mathrm{ml}$ of FC reagent was added and sample was incubated for $3 \mathrm{~min}$, followed by addition of $2 \mathrm{ml}$ of $\mathrm{Na}_{2} \mathrm{CO}_{3}$ and samples were placed in boiling water for $1 \mathrm{~min}$. The reaction mixture was allowed to cool and then absorbance was recorded at $765 \mathrm{~nm}$ on Chemito Spectrascan UV2600 spectrophotometer. The total phenolic content was expressed as mg gallic acid equivalents (GAE) $\mathrm{g}^{-1}$ extract calculated using standard gallic acid calibration graph.

\subsection{Determination of total flavonoids}

Total flavonoids were estimated using modified Marinova et al ${ }^{19}$ method. Briefly, $10 \mu \mathrm{l}$ plant extract was added to distilled water to make a final volume of $2 \mathrm{ml}$ and kept at room temperature for $3 \mathrm{~min}$. To this, $3 \mathrm{ml}$ of $5 \% \mathrm{NaNO}_{2}$ and $0.3 \mathrm{ml}$ of $\mathrm{AlCl}_{3}$ was added. After 6 min incubation, $2 \mathrm{ml} 1 \mathrm{M} \mathrm{NaOH}$ was added and volume was made $10 \mathrm{ml}$ with distilled water. Absorbance was taken at $510 \mathrm{~nm}$ and the concentration of flavonoid compounds was expressed as $\mathrm{mg}$ quercetin equivalents per $\mathrm{g}$ extract.

\subsection{Determination of total ascorbic acid}

Total ascorbic acid was estimated by 2,4-dinitrophenylhydrazine (DNPH) method as described earlier. ${ }^{20}$ Ten microliter of each extract was separately taken and total volume was made to $2 \mathrm{ml}$ with distilled water. To this $2 \mathrm{ml}$ of DNPH and 1 drop of $10 \%$ thiourea was added, the mixture was heated in a boiling water bath for $15 \mathrm{~min}$ and cooled to room temperature. Five microliter of $80 \%(\mathrm{v} / \mathrm{v}) \mathrm{H}_{2} \mathrm{SO}_{4}$ was added to the mixture at $0{ }^{\circ} \mathrm{C}$ in an ice bath. Absorbance was taken at $521 \mathrm{~nm}$ and ascorbic acid was used as standard.

\subsection{Determination of total carotenoid content}

For estimation of total carotenoids, 10 microliter plant extract was added to distilled water to make a final volume of $2 \mathrm{ml}$. To this, $3.75 \mathrm{ml}$ of $10 \%$ methanolic $\mathrm{KOH}$ and $3.75 \mathrm{ml}$ diethyl ether was added. The reaction mixture was washed with $5 \%$ ice cold saline and dried over anhydrous $\mathrm{Na}_{2} \mathrm{SO}_{4}$ for $2 \mathrm{~h}$. The absorbance of the filtrate was taken at $450 \mathrm{~nm}$ and concentration of carotenoids was expressed as $\mathrm{mg} \beta$-carotene equivalents per g extract. ${ }^{21}$

\subsection{Antioxidant activities}

\subsubsection{Total antioxidant activity (TAA)}

Total antioxidant activity was determined using modified phosphomolybdenum method. ${ }^{22}$ The assay is based on the reduction of $\mathrm{Mo}(\mathrm{VI})$ to $\mathrm{Mo}(\mathrm{V})$ by sample compound and formation of green colored phosphate/Mo(V) complex at acidic $\mathrm{pH}(4.0) .0 .1 \mathrm{ml}$ of extract from varying concentrations $\left(200-1000 \mu \mathrm{g} \mathrm{ml}^{-1}\right)$ was added to $1 \mathrm{ml}$ reagent solution $\left(0.6 \mathrm{M} \mathrm{H}_{2} \mathrm{SO}_{4}, 28 \mathrm{mM}\right.$ sodium phosphate and $4 \mathrm{mM}$ ammonium molybdate). The mixture was incubated at $95^{\circ} \mathrm{C}$ for 90 min and the absorbance was measured at $695 \mathrm{~nm}$ after cooling the samples. Total antioxidant capacity was expressed as GAE.

\subsubsection{FRAP (ferric reducing antioxidant power)}

The antioxidant capacity of $E$. nuda extracts was estimated spectrophotometrically. ${ }^{23}$ The method is based on reduction of $\mathrm{Fe}^{3+}$ - tetra (2-pyridyl) pyrazine (TPTZ) complex to $\mathrm{Fe}^{2+}$-tripyridyltriazine formed by action of electron donating antioxidants at low pH. FRAP reagent was prepared by the addition of $300 \mathrm{mM}$ acetate buffer $10 \mathrm{ml} \mathrm{TPTZ}$ dissolved in $40 \mathrm{mM} \mathrm{HCl}$ and $20 \mathrm{mM}$ $\mathrm{FeCl}_{3} \cdot 6 \mathrm{H}_{2} \mathrm{O}$ in the ratio 10:1:1. Five hundred microliter of standard was added to $1 \mathrm{ml}$ of FRAP and the mixture was incubated at $37^{\circ} \mathrm{C}$ for $30 \mathrm{~min}$. Absorbance was recorded at $593 \mathrm{~nm}$ against blank. The 
values of FRAP were expressed as GAE for varying concentrations of the extracts $\left(200-1000 \mu \mathrm{g} \mathrm{ml}^{-1}\right)$.

\subsubsection{ABTS radical scavenging assay}

Free radical scavenging activity of plant extracts was determined by ABTS radical decolorization assay. ${ }^{24}$ In brief, ABTS ${ }^{+}\left(2,2^{\prime}-\right.$ azino-bis-3-ethylbenzthiazoline-6-sulphonic acid cation radical) was produced by the reaction between $7 \mathrm{mM} \mathrm{ABTS}$ in water and $2.45 \mathrm{mM}$ potassium persulfate in water (1:1). This reaction mixture was stored in dark at room temperature for $16-20 \mathrm{~h}$. This ABTS- ${ }^{+}$ solution was then diluted with methanol to get absorbance of 0.7 at $734 \mathrm{~nm}$. Five microliter of plant extract was added to $3.995 \mathrm{ml}$ of ABTS ${ }^{+}$solution and incubated for $30 \mathrm{~min}$ and absorbance was measured at $734 \mathrm{~nm}$. The results were expressed as percent scavenging effect of plant extracts.

\subsubsection{DPPH radical scavenging activity}

The antioxidant activity of the plant extract was examined on the basis of the scavenging effect on the stable 1,1-diphenyl-2picrylhydrazyl (DPPH) free radical activity as described by Braca et al. ${ }^{25}$ Ethanolic solution of DPPH $0.05 \mathrm{mM}(300 \mu \mathrm{l})$ was added to $40 \mu \mathrm{l}$ of extract of different concentrations (200-1000 $\mu \mathrm{g} \mathrm{ml}^{-1}$ ). After 5 min, absorbance was measured spectrophotometrically at $517 \mathrm{~nm}$ against extract blank. The radical scavenging activity of the plant extract, expressed as percent inhibition was calculated according to the following equation:

\section{Percent inhibition of DPPH radical $=$ \\ [(absorbance control - absorbance test) \\ /absorbance control $] \times 100$}

\subsubsection{Hydroxyl radical scavenging activity}

Hydroxyl radical scavenging activity was measured by studying the competition between deoxyribose and test extract for hydroxyl radical generated by Fenton's reaction. ${ }^{26}$ The reaction mixture contained deoxyribose $\left(2.8 \mathrm{mM}\right.$ in $\mathrm{KH}_{2} \mathrm{PO}_{4}-\mathrm{KOH}$ buffer, $\left.\mathrm{pH} 7.4\right)$, $\mathrm{FeCl}_{3}(0.1 \mathrm{mM})$, EDTA $(0.1 \mathrm{mM}), \mathrm{H}_{2} \mathrm{O}_{2}(1 \mathrm{mM})$, ascorbate $(0.1 \mathrm{mM})$, and various concentrations of the sample extracts (200$1000 \mu \mathrm{g} \mathrm{ml}^{-1}$ ) in a final volume of $1.0 \mathrm{ml}$. The reaction mixture was incubated for $1 \mathrm{~h}$ at $37^{\circ} \mathrm{C}$. Deoxyribose degradation was measured using thiobarbituric acid (TBA) assay. One $\mathrm{ml}$ of TBA (1\%) and $1 \mathrm{ml}$ of TCA (2.8\%) was added to above mixture and incubated at $100{ }^{\circ} \mathrm{C}$ for $20 \mathrm{~min}$. The development of pink color was measured at $532 \mathrm{~nm}$ and percent inhibition was calculated.

\subsubsection{Determination of inhibition of lipid peroxidation}

Lipid peroxidation inhibition potential of $E$. nuda extracts were evaluated in vitro by following the modified Halliwell and Gutteridge $^{27}$ method. Briefly, freshly excised goat liver was minced using glass Teflon homogenizer in cold phosphate buffered saline, $\mathrm{pH}$ 7.4. Ten percent homogenate was prepared and then was filtered to obtain a clear homogenate. The process of homogenization and filtration was carried on ice. Different concentrations of the extracts (200-1000 $\mathrm{g} \mathrm{ml}^{-1}$ ) in water were added to the liver homogenate. Lipid peroxidation was initiated by adding $100 \mu \mathrm{l}$ of $15 \mathrm{mM}$ ferrous sulfate solution to $3 \mathrm{ml}$ of the tissue homogenate. After $30 \mathrm{~min}$, $100 \mu \mathrm{l}$ of this reaction mixture was taken in a tube containing $1.5 \mathrm{ml}$ of $10 \%$ TCA. After $10 \mathrm{~min}$, tubes were centrifuged and supernatant was separated and mixed with $1.5 \mathrm{ml}$ of $0.67 \%$ TBA in $50 \%$ acetic acid. The mixture was heated for $30 \mathrm{~min}$ in a boiling water bath. The intensity of the pink colored complex was measured at $535 \mathrm{~nm}$. The degree of lipid peroxidation was assayed by estimating the TBARS (TBA-reactive substances) content. The results were expressed as percentage inhibition using the formula:
Percent inhibition of lipid peroxidation $=$ [(absorbance control - absorbance test) /absorbance control $] \times 100$

\subsection{DNA protection activity}

The ability of different extracts to protect DNA (pBR322, Merck, India) from damaging effects of hydroxyl radicals generated by Fenton's reagent was assessed by DNA nicking assay ${ }^{28}$ with minor modifications. The reaction mixture contained $2.5 \mu \mathrm{l}$ of DNA $(0.25 \mu \mathrm{g})$ and $10 \mu \mathrm{l}$ Fenton's reagent $\left(30 \mathrm{mM} \mathrm{H}_{2} \mathrm{O}_{2}, 500 \mu \mathrm{M}\right.$ ascorbic acid and $800 \mu \mathrm{M} \mathrm{FeCl}_{3}$ ) followed by the addition of $5 \mu \mathrm{l}$ extract and the final volume of the mixture was brought up to $20 \mu \mathrm{l}$ with distilled water. The reaction mixture was then incubated for $45 \mathrm{~min}$ at $37{ }^{\circ} \mathrm{C}$ and followed by addition of $2.5 \mu$ l loading buffer $(0.25 \%$ bromophenol blue, $50 \%$ glycerol). The results were analyzed on $0.8 \%$ agarose gel electrophoresis by staining with ethidium bromide. Quercetin was used as positive control.

\subsection{Statistical analyses}

All experiments were conducted in triplicate to check the reproducibility of the results obtained. The graphs were plotted using Microcal Origin 6.0. The results are presented as means \pm standard error (SE) and means were compared using Duncan's Multiple Range Test (DMRT) at $P \leq 0.05$, using MSTAT-C statistical software.

\section{Results and discussion}

Quantitative evaluation of phytochemicals, known for their roles in providing antioxidant properties to plants, from tuber extracts of E. nuda indicated the plant as a rich source of phenolics, flavonoids, ascorbic acid and carotenoids, though with solvent dependent variations in their contents (Table 1). Several reports have shown a correlation between higher amounts of total polyphenols in plants and correspondingly higher antioxidant potential. ${ }^{18,28-32}$ Our results also largely supported these conclusions. In the present study, overall, methanol extract (ME) showed maximum amounts of total phenols, flavonoids, ascorbic acid and carotenoids closely followed by aqueous methanol (AqME) extract. Total phenol content in tuber extracts expressed as gallic acid equivalent (GAE) were found in the range of $16.2-24.5 \mathrm{mg} \mathrm{GAE} \mathrm{g}^{-1}$ extract (Table 1). Total flavonoids were comparably in lesser quantities than total phenols in all the extracts, where ME showed highest concentrations ( $22.2 \mathrm{mg} \mathrm{AAE}^{-1}$ ) followed by AqME with

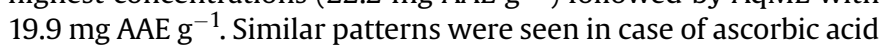
and carotenoids as evidenced from the results presented in Table 1.

Even though free radical generation and oxidation process are intrinsic in energy management of all living organisms and are kept under strict control by several cellular mechanisms, ${ }^{33}$ however, if

Table 1

Total phenols, flavonoids, ascorbic acid and carotenoid contents of E. nuda extracts.

\begin{tabular}{|c|c|c|c|c|}
\hline Extract & $\begin{array}{l}\text { Total phenols } \\
(\text { mean } \pm \text { SE) }\end{array}$ & $\begin{array}{l}\text { Flavonoids } \\
(\text { mean } \pm \mathrm{SE})\end{array}$ & $\begin{array}{l}\text { Ascorbic acid } \\
(\text { mean } \pm S E)\end{array}$ & $\begin{array}{l}\text { Carotenoids }^{\$} \\
(\text { mean } \pm \mathrm{SE})\end{array}$ \\
\hline $\mathrm{AE}$ & $23.3 \pm 0.8^{b}$ & $16.4 \pm 0.5^{b}$ & $29.1 \pm 2.1^{a}$ & $0.8 \pm 0.1^{\mathrm{a}}$ \\
\hline ME & $24.5 \pm 0.6^{c}$ & $22.2 \pm 1.8^{\mathrm{d}}$ & $75.6 \pm 3.9^{d}$ & $3.0 \pm 0.3^{c}$ \\
\hline AqME & $24.2 \pm 1.1^{c}$ & $19.9 \pm 0.2^{c}$ & $50.0 \pm 1.8^{c}$ & $2.7 \pm 0.2^{b}$ \\
\hline $\mathrm{AqE}$ & $16.2 \pm 0.8^{\mathrm{a}}$ & $6.6 \pm 0.2^{a}$ & $40.4 \pm 1.5^{\mathrm{b}}$ & $2.5 \pm 0.2^{\mathrm{b}}$ \\
\hline
\end{tabular}

*Gallic acid; quercetin; ${ }^{*}$ ascorbic acid and ${ }^{\$} \beta$-carotene equivalents $\mathrm{mg} \mathrm{g}^{-1}$ extract. Each value represents the mean of three replications \pm SE. Means within a column followed by different superscript letters were significantly different from each other according to Duncan's Multiple Range Test (DMRT) at $P \leq 0.05$. 
the supply of oxygen is in excess or its reduction is insufficient, ROS are generated that causes cellular injuries and initiate peroxidation of polyunsaturated fatty acids in biological membranes. In recent years, the scientific community has strongly advocated exploration and use of plant-origin natural effective antioxidants, especially from edible plants and their parts as they have less or no side effects than their synthetic counterparts. ${ }^{10,34}$ Therefore, in the present study, E. nuda known for its enormous medicinal properties in folklore was selected for the first time for evaluating its antioxidant properties.

Antioxidant activity is generally attributed to phytochemicals present, a number of mechanisms in plants and the synergies between them. Thus, antioxidant activity of plant extracts cannot be evaluated by a single method. ${ }^{10,35}$ Hence, in order to explore and understand these possible mechanisms, several antioxidant assays including TAA, FRAP, ABTS, DPPH and OH radical scavenging assays were performed for evaluating antioxidant activities of $E$. nuda. The results confirmed that this plant has a broad range of antioxidant properties, including substantial inhibition of lipid peroxidation. The results of TAA and FRAP scavenging activity are summarized in Table 2. Amongst all the four extracts, again ME showed highest

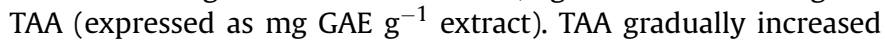
with the concentration of extract from 200 to $1000 \mu \mathrm{g} \mathrm{ml}^{-1}$ irrespective of extract nature (Table 2). FRAP is an important indicator of reducing potential of an antioxidant which is associated with the presence of compounds responsible for breaking the free radical chain through donation of hydrogen atom. ${ }^{36}$ The results showed noticeable antioxidant potential (in terms of FRAP measured as GAE) of all the extracts of $E$. nuda tubers, which was gradually increased with increasing concentrations of samples. The FRAP assay provides a reliable method for evaluation of antioxidant activities of various plant extracts and compounds as antioxidant capacity is directly correlated with its reducing capacity ${ }^{23}$ and our results are in conformity of these findings.

Fig. 1 depicts the results of ABTS radical scavenging activities of all the extracts as well as gallic acid (standard antioxidant compound). AqME showed highest capacity to scavenge ABTS cation radical amongst all the extracts, however the activities were inferior to gallic acid, and therefore the standard was used at comparably low range $\left(20-100 \mu \mathrm{g} \mathrm{ml}{ }^{-1}\right)$ than the extracts $(200-$ $1000 \mu \mathrm{g} \mathrm{ml}^{-1}$ ), respectively. Proton radical scavenging is considered as an important attribute of antioxidants. ABTS, a protonated radical, has characteristic absorbance maxima at $734 \mathrm{~nm}$ which decreases with the scavenging of the proton radicals. ${ }^{8}$ The magnitude of free-radical quenching was dose-dependent and steadily increased with increase in plant sample concentrations (Fig. 1).

DPPH is a stable free radical and the DPPH assay based on its reduction by antioxidant is most commonly used model system for studying antioxidant capacity of plant extracts or pure compounds to act as free radical scavengers or hydrogen donors. 8,37 All the extracts showed significantly high tendency to quench the DPPH radicals, as indicated by the dose-dependent increase in inhibition

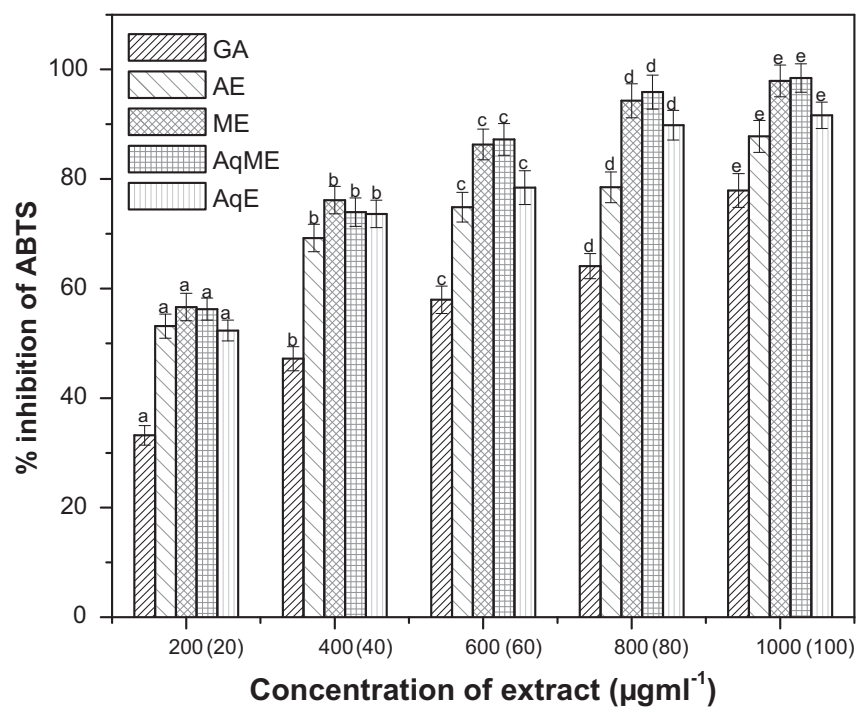

Fig. 1. ABTS radical scavenging activities of various extracts of $E$. muda. The values in parenthesis represent the concentration of gallic acid $\left(20-100 \mu \mathrm{g} \mathrm{ml}^{-1}\right)$. Each value represents the mean of three replications \pm SE. The bars with different letters are significantly different from each other at $P \leq 0.05$ according to Duncan's Multiple Range test.

percentage (Fig. 2). AqME showed strongest radical scavenging activity in comparison with other extracts, and its percentage inhibition reached $87.29 \%$ at $1 \mathrm{mg} \mathrm{ml}^{-1}$ concentration ( $\mathrm{IC}_{50}$ value: $330 \mu \mathrm{g} \mathrm{ml}^{-1}$ ), which was significantly higher even than the standard (ascorbic acid, 68.81\%) at the same concentration and an $\mathrm{IC}_{50}$ value of $804 \mu \mathrm{g} \mathrm{ml}^{-1}$. Similar to our findings, several authors have attributed the antioxidant potential of plants to higher DPPH radical scavenging activity. ${ }^{18,30,32,38}$

Among the four extracts used, acetone extract did not show inhibition of $\mathrm{OH}$ radical generation at concentrations ranging from 200 to $1000 \mu \mathrm{g} \mathrm{ml}^{-1}$ (Fig. 3). AqME again showed notably higher hydroxyl radical scavenging activity $\left(\mathrm{IC}_{50}\right.$ value: $230 \mu \mathrm{g} \mathrm{ml}^{-1}$ ) than other extracts as well as the standard (ascorbic acid, $\mathrm{IC}_{50}$ value: $617 \mu \mathrm{g} \mathrm{ml}^{-1}$ ). The radical scavenging activity was found to be concentration dependent and was increased with concentrations of all the extracts and standard antioxidant as well (Fig. 3). Hydroxyl radical is an extremely reactive ROS which initiates auto-oxidation and attacks almost every biological molecule causes damage to DNA, protein and lipids leading to mutagenesis, carcinogenesis and aging. ${ }^{28,30,33}$ The plants with higher $\mathrm{OH}$ radical scavenging holds great importance as their consumption can result in controlling and mitigating the devastating effects of oxidative stresses. ${ }^{18,38}$ The current results are of great importance as the extracts especially AqME exhibited great potential in scavenging the $\mathrm{OH}$ radicals.

The inhibition of lipid peroxidation is considered as the most important index of antioxidant activity as reported by various

Table 2

FRAP and total antioxidant activities (TAA) of E. nuda extracts.

\begin{tabular}{|c|c|c|c|c|c|c|c|c|}
\hline \multirow{2}{*}{$\begin{array}{l}\text { Conc. of extracts } \\
\left(\mu \mathrm{g} \mathrm{ml}^{-1}\right)\end{array}$} & \multicolumn{4}{|c|}{ TAA of various extracts (GAE) (mean $\pm \mathrm{SE})$} & \multicolumn{4}{|c|}{ FRAP of various extracts $(\mathrm{GAE})($ mean $\pm \mathrm{SE})$} \\
\hline & $\mathrm{AE}$ & ME & AqME & $\mathrm{AqE}$ & $\mathrm{AE}$ & $\mathrm{ME}$ & AqME & $\mathrm{AqE}$ \\
\hline 200 & $64 \pm 2.1^{\mathrm{a}}$ & $70 \pm 3.3^{a}$ & $27 \pm 1.6^{\mathrm{a}}$ & $21 \pm 1.1^{\mathrm{a}}$ & $200 \pm 2.5^{\mathrm{a}}$ & $272 \pm 2.9^{a}$ & $251 \pm 4.5^{\mathrm{a}}$ & $189 \pm 3.5^{\mathrm{a}}$ \\
\hline 400 & $66 \pm 2.4^{\mathrm{a}}$ & $95 \pm 3.1^{b}$ & $41 \pm 2.3^{b}$ & $23 \pm 1.4^{\mathrm{a}}$ & $233 \pm 3.2^{b}$ & $301 \pm 5.4^{\mathrm{b}}$ & $258 \pm 5.2^{b}$ & $201 \pm 5.4^{b}$ \\
\hline 600 & $68 \pm 2.7^{\mathrm{a}, \mathrm{b}}$ & $132 \pm 4.7^{c}$ & $54 \pm 3.1^{c}$ & $26 \pm 1.1^{\mathrm{b}}$ & $251 \pm 2.9^{c}$ & $330 \pm 3.8^{c}$ & $259 \pm 5.0^{\mathrm{b}}$ & $210 \pm 5.5^{c}$ \\
\hline 800 & $70 \pm 3.1^{\mathrm{b}, \mathrm{c}}$ & $138 \pm 4.4^{\mathrm{d}}$ & $63 \pm 2.8^{d}$ & $30 \pm 1.5^{c}$ & $272 \pm 3.8^{\mathrm{d}}$ & $353 \pm 3.7^{d}$ & $271 \pm 4.7^{c}$ & $222 \pm 5.8^{\mathrm{d}}$ \\
\hline 1000 & $75 \pm 3.4^{\mathrm{d}}$ & $160 \pm 5.1^{\mathrm{e}}$ & $88 \pm 3.6^{\mathrm{e}}$ & $35 \pm 1.8^{\mathrm{d}}$ & $290 \pm 4.3^{\mathrm{e}}$ & $381 \pm 4.9^{\mathrm{e}}$ & $292 \pm 3.9^{\mathrm{d}}$ & $231 \pm 4.6^{\mathrm{e}}$ \\
\hline
\end{tabular}

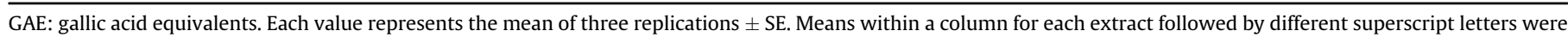
significantly different from each other according to Duncan's Multiple Range Test (DMRT) at $P \leq 0.05$. 


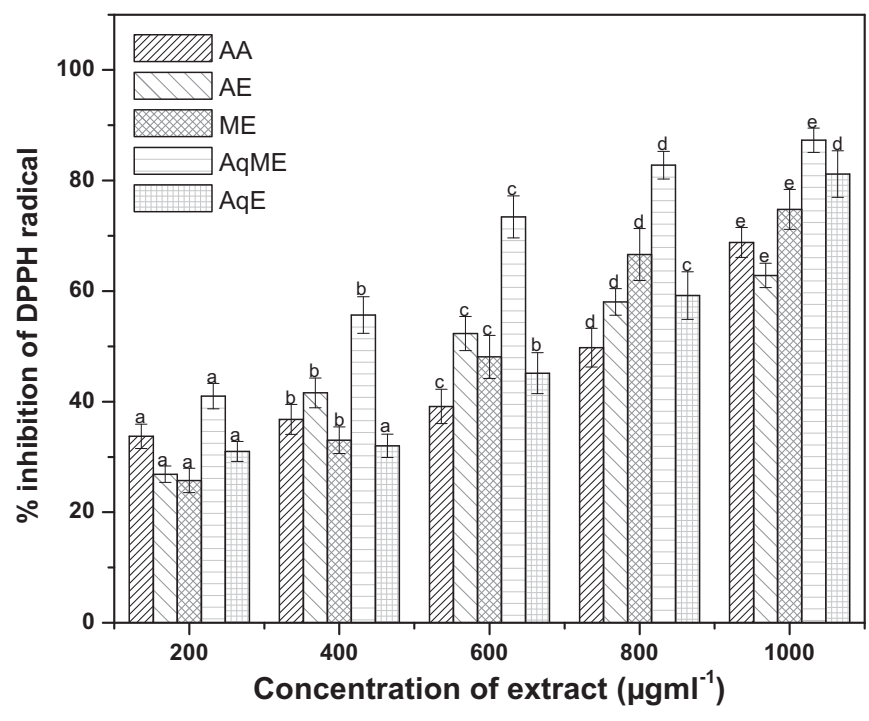

Fig. 2. DPPH radical scavenging activities of various extracts of $\boldsymbol{E}$. nuda. Each value represents the mean of three replications \pm SE. The bars with different letters are significantly different from each other at $P \leq 0.05$ according to Duncan's Multiple Range test.

investigators. ${ }^{18,31,38}$ In the present investigation, in vitro lipid peroxidation was induced in goat liver by $\mathrm{FeSO}_{4}$ which takes place through $\mathrm{OH}$ radical generation by Fenton's reaction. E. nuda tuber extracts showed significant inhibition of lipid peroxidation rate measured in terms of TBARS, an indicator of malondialdehyde (MDA) content which is a degradation product of lipid peroxidation (Fig. 4). The results hold great significance as AqME showed tremendous potential in terms of inhibition percentage of lipid peroxidation, and showed $100 \%$ inhibition at $1000 \mu \mathrm{g} \mathrm{ml}^{-1}$ concentration followed by ME (96\% inhibition) against standard ascorbic acid with $90 \%$ inhibition at similar concentration (Fig. 4). AqME thus offered a good degree of protection against the biological end-point of oxidative damage. Lipid peroxidation induces cellular damage that eventually leads to many human diseases. ${ }^{31,34}$

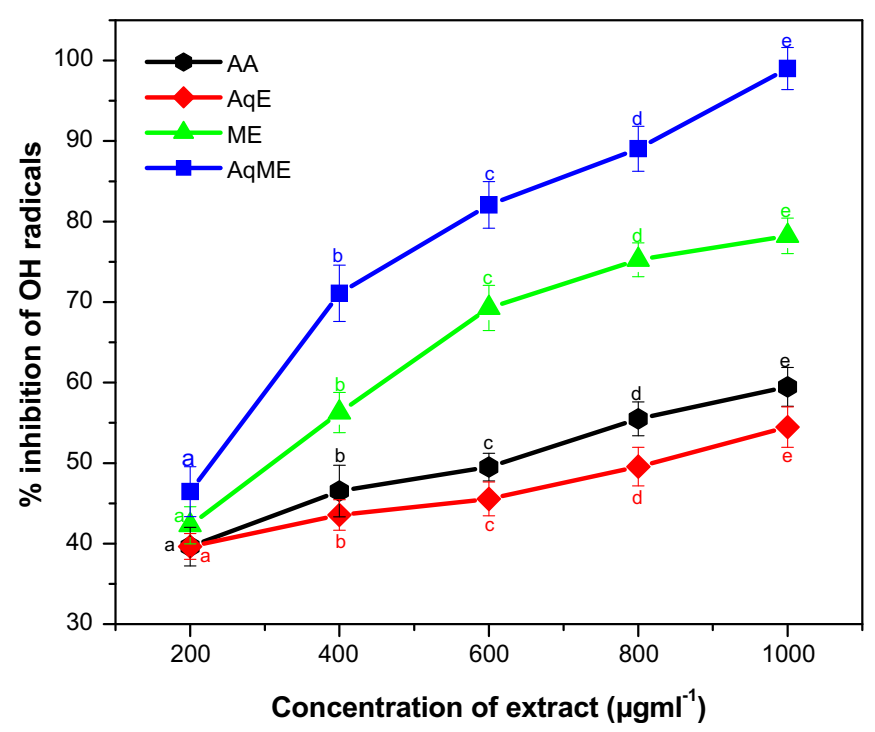

Fig. 3. Hydroxyl radical scavenging activities of various extracts of $E$. nuda. Each value represents the mean of three replications \pm SE. The lines with the same color and symbol with different letters are significantly different from each other at $P \leq 0.05$ according to Duncan's Multiple Range test.

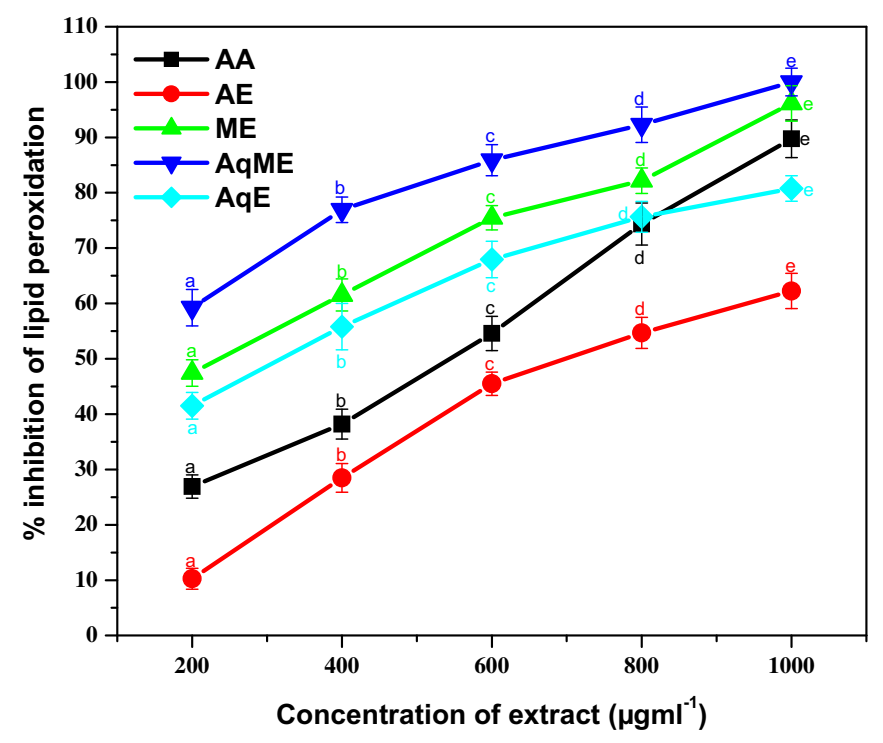

Fig. 4. Inhibition of lipid peroxidation in goat liver by various extracts of $E$. nuda. Each value represents the mean of three replications \pm SE. The lines with the same color and symbol with different letters are significantly different from each other at $P \leq 0.05$ according to Duncan's Multiple Range test.

Antioxidant may offer resistance against the oxidative stress by scavenging the free radicals, inhibiting the lipid peroxidation and thus prevent diseases.

All the extracts were evaluated for their oxidative damage protective activity against a model DNA pBR322. Hydroxyl radicals generated by Fenton's reaction are known to cause DNA damage, as DNA band is absent in Fig. 5, lane 3 and only a smear of degraded DNA can be observed. Even though all the extracts effectively mitigated the oxidative stress and protected the DNA from hydroxyl radicals generated by Fenton's reaction, as confirmed by the presence of DNA bands, aqueous methanol extract (Fig. 5, lane 6) seems to be comparably most effective in maintaining the DNA intact followed by aqueous (Fig. 5, lane 4), acetone (Fig. 5, lane 7) and methanol extract (Fig. 5, lane 5), respectively. Standard antioxidant compound quercetin was also used for comparison with plant extracts $\left(50 \mu \mathrm{g} \mathrm{ml}^{-1}\right.$ each) for DNA protection efficacy. Free radicals are known for DNA strand breaking and damage which eventually contributes to carcinogenesis, mutagenesis and cytotoxicity. ${ }^{3,5}$ Various researchers have reported the similar results and used plant extracts and fractions for DNA protection against oxidative damage. ${ }^{3,5,39}$

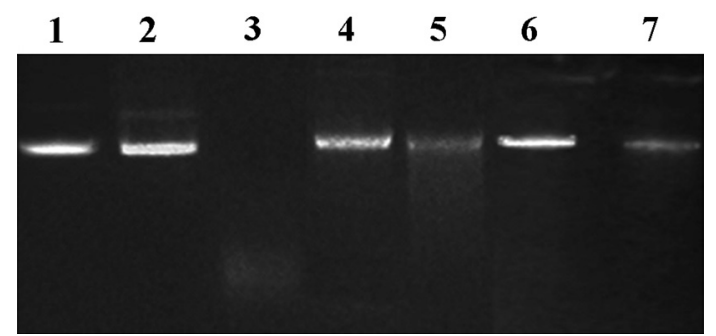

Fig. 5. DNA damage protecting effect of aqueous, aqueous methanol, methanol and acetone extracts of tubers of Eulophia nuda against hydroxyl radicals induced DNA damage of pBR322. Lane 1: native pBR322 plasmid DNA; Lane 2: DNA + Fenton's reagent + quercetin $\left(50 \mu \mathrm{g} \mathrm{ml}^{-1}\right.$, positive control); Lane 3: DNA + Fenton's reagent (DNA damage control); Lane 4: DNA + Fenton's reagent + AqE; Lane 5: DNA + Fenton's reagent + ME; Lane 6: DNA + Fenton's reagent + AqME; Lane 7: DNA + Fenton's reagent $+\mathrm{AE}$. 


\section{Conclusion}

It can be concluded that $E$. nuda contains considerable amount of total phenols, flavonoids, vitamin $\mathrm{C}$ and carotenoids and showed solvent-dependent variations in their quantities. Various in vitro antioxidant assays clearly indicated that the plant extracts exhibited broad spectrum of antioxidant properties mediated by effective scavenging of various free radicals and subsequently inhibited the lipid peroxidation. Amongst all the extracts AqME showed considerably higher antioxidant activities than other extracts. The plant extracts successfully protected the DNA from damage caused by free radicals. Overall, methanol and aqueous methanol extracts showed great promise and should therefore be used further for fractionation and isolation of pure compound responsible for antioxidant activities.

\section{Conflicts of interest}

All authors have none to declare.

\section{Acknowledgments}

Authors thank the Principals of Modern College, Ganeshkhind, Pune and Prof. Ramkrishna More College, Akurdi, Pune for encouragement and support to carry out this work.

\section{References}

1. Kohen R, Nyska A. Oxidation of biological systems: oxidative stress phenomena, antioxidants, redox reactions, and methods for their quantification. Toxicol Pathol. 2002;30:620-650.

2. Samarkoon SMS, Chandola HM, Shukla VJ. Evaluation of antioxidant potential of Amalkayas Rasayana: a polyphenol Ayurvedic formulation. Int J Ayurveda Res. 2011;2:23-28.

3. Poorna CA, Resmi MS, Soniya EV. In vitro antioxidant analysis and the DNA damage protective activity of Leaf extract of the Excoecaria agallocha Linn Mangrove plant. In: Stoytcheva M, Zlatev R, eds. Agricultural Chemistry. New York: InTech; 2013:155-166.

4. Zahin M, Ahmad I, Aqil F. Antioxidant and antimutagenic activity of Carum copticum fruits extracts. Toxicol In Vitro. 2010;24:1243-1249.

5. Kumar M, Kumar S, Kaur S. Investigations on DNA protective and antioxidant potential of chloroform and ethyl acetate fractions of Koelreuteria paniculata Laxm. Afr J Pharm Pharmacol. 2011;5:421-427.

6. Repetto MG, Llesuy SF. Antioxidant properties of natural compounds used in popular medicine for gastric ulcers. Braz J Med Biol Res. 2002;35:523-534.

7. Surh YJ, Ferguson LR. Dietary and medicinal antimutagens and anticarcinogens: molecular mechanisms and chemopreventive potential-highlights of a symposium. Mutat Res. 2003;1:523-524.

8. Mayakrishnan V, Veluswamy S, Sundaram KS, Kannappan P, Abdullah N. Free radical scavenging potential of Lagenaria siceraria (Molina) Standl fruits extract. Asian Pac J Trop Med. 2012;2:20-26.

9. Bendiabdellah A, Dib MAA, Meliani N, Djabou N, Allali H, Tabti B. Preliminary phytochemical screening and antioxidant activities of solvent extracts from Daucus crinitus Desf. from Algeria. J Appl Pharm Sci. 2012;2:92-95.

10. Salar R, Seasotiya L. Free radical Scavenging activity, phenolic contents and phytochemical evaluation of different extracts of stem, bark of Butea monosperma (Lam.) Kuntze. Front Life Sci. 2011;5:107-116.

11. Kirtikar KR, Basu BD. Indian Medicinal Plants. Allahabad: Sudhindra Nath Basu; 1918:1242-1243.

12. The Wealth of India. A Dictionary of Indian Raw Materials and Industrial Products: Raw Materials. vol. 2. New Delhi: Council of Scientific Industrial Research; 1952:221.

13. Chopra RN, Nayar SL, Chopra IC. Glossary of Indian Medicinal Plants. New Delhi: Council of Scientific and Industrial Research; 1956.
14. Cooke T. The Flora of the Presidency of Bombay. Calcutta: Botanical Survey of India; 1967:197-198.

15. Nadkarni KM. Indian Materia Medica. Mumbai: Popular Prakashan; 1976:519.

16. Mali PY, Bhadane VV. Some rare plants of ethnomedicinal properties from Jalgaon District, Maharashtra. Int J Green Pharm. 2008;1:76-78.

17. Shriram V, Kumar V, Kishor PBK, Suryawanshi SB, Upadhyay AK, Bhat MK. Cytotoxic activity of 9,10-dihydro-2,5-dimethoxyphenanthrene-1,7-dio from Eulophia nuda against human cancer cells. J Ethnopharmacol 2010;128:251-253.

18. Gul M, Bhakshu L, Ahmed F, Anand K, Qureshi I, Ghazi I. Evaluation of Abel moschus moschatus extracts for antioxidant, free radical scavenging, antimicrobial and antiproliferative activities using in vitro assays. BMC Complement Altern Med. 2011;11:64.

19. Marinova D, Ribarova F, Atanassova M. Total phenolics and total flavonoids in Bulgarian fruits and vegetables. J Univ Chem Technol Metall. 2005;40:255-260.

20. Kapur A, Haskovic A, Copra-Janicijevic A, et al. Spectrophotometric analysis of total ascorbic acid content in various fruits and vegetables. Bull Chem Technol Bosnia Herzegovina. 2012;38:40-43.

21. Jensen A. In: Hallebust JA, Craigie JS, eds. Chlorophyll and Carotenoids, in Handbook of Physiochemical and Biochemical Methods. Cambridge: Cambridge University Press; 1978:5-70.

22. Prieto P, Pineda M, Aguilar M. Spectrophotometric quantitation of antioxidant capacity through the formation of phosphomolybdenum complex: specific application to determination of vitamin. Anal Biochem. 1999;269:337-341.

23. Benzie IF, Strain JJ. Ferric reducing antioxidant power assay: direct measure of total antioxidant activity of total biological fluids and modified version for simultaneous measurement of total antioxidant power and ascorbic acid concentration. Meth Enzymol. 1999;299:15-27.

24. Re R, Pellegrini N, Proteggente A, Yang M, Rice-Evans C. Antioxidant activity applying an improved ABTS radical cation decolorization assay. Free Radic Biol Med. 1999;26:1231-1237.

25. Braca A, Sortino C, Politi M, Morelli I, Mendez J. Antioxidant activity of flavonoids from Licania licaniaeflora. J Ethnopharmacol. 2002;79:379-381.

26. Kunchandy E, Rao MNA. Oxygen radical scavenging activity of curcuminoid. Int J Pharm. 1990;58:235-242.

27. Halliwell B, Gutteridge JMC. Protection against Lipid Peroxidation, in Free Radicals in Biology and Medicine. Tokyo: Japan Scientific Societies Press; 1989:2.

28. Lee JC, Kim HR, Kim J, Jang YS. Antioxidant property of an ethanol extract of the stem of Opuntia ficus-indica var. saboten. J Agric Food Chem. 2002;50:64906496.

29. Das M, Sarma B, Ahmed G, Balasubramanium N, Choudhury M. In vitro antioxidant and total phenolic content of Dillenia indica and Garcinia penducalata, commonly used fruits in Assamese cuisine. Free Rad Antiox. 2012;2:30-36.

30. Dureja AG, Dhiman K. Free radical scavenging potential and total phenolic and flavonoid content of Ziziphus mauritiana and Ziziphus nummularia fruit extracts. Int J Green Pharm. 2012;6:187-192.

31. Nagmoti DM, Khatri DK, Juvekar PR, Juvekar AR. Antioxidant activity and free radical-scavenging potential of Pithecellobium dulce Benth seed extracts. Free Rad Antiox. 2012;2:37-43.

32. Talukdar D. In vitro antioxidant potential and type II diabetes related enzyme inhibition properties of traditionally processed legume based food and medicinal recopies in Indian Himalayas. J Appl Pharm Sci. 2013;3:26-32.

33. Halliwell B, Gutteridge JMC. Free Radicals in Biology and Medicine. Oxford: Oxford University Press; 2007.

34. Liu H, Qiu N, Ding H, Yao R. Polyphenol content and antioxidant capacity of 68 Chinese herbals suitable for medical or food uses. Food Res Int. 2008;41: 363-370.

35. Hall CA, Cuppett SL. Activities of natural antioxidants. In: Aruoma OI, Cuppett SL, eds. Antioxidant Methodology in Vivo and in Vitro Concepts. Champaign (IL): AOCS Press; 1997:2-29.

36. Othman A, Ismail A, Abdul Ghani N, Adenan I. Antioxidant capacity and phenolic content of cocoa beans. Food Chem. 2007;100:1523-1530.

37. Prathapan A, Singh MK, Anusree SS, Kumar DRS, Sundaresan A, Raghu KG. Antiperoxidative, free radical scavenging and metal chelating activities of Boerhaavia diffusa L. J Food Biochem. 2011;35:1548-1554.

38. Baskar R, Rajeshwari V, Kumar T. In vitro antioxidant studies in leaves of Annona species. Indian J Exp Biol. 2007;45:480-485.

39. Chaudhary A, Rampal G, Sharma U, et al. Anticancer, antioxidant activities and GC-MS analysis of glucosinolates in two cultivars of broccoli. Med Chem Drug Dis. 2012;2:30-37. 